\section{Conservation of Natural Resources}

"The Conservation of Natural Resources" is a series of lectures delivered at the Institution of Civil Engineers during 1956 (London : Institution of Civil Engineers, 1957. 17s.6d.; 7s.6d. to members). The topic is a vital one for the whole world and particularly so in a small crowded country like Great Britain. Although the primary responsibility for action in this field lies with the Government it is the engineer who has to appraise and solve the problem. There aro seven lectures in all. "The Engineer's Contribution to the Conservation of Natural Resources" by Sir Harold Hartley deals mainly with the past. Prof. W. R. Jones in "Mineral Resources" points out that since we have plonty of iron, aluminium and magnesium in the sea the future of a steel/light alloy/concrete economy is assured. Prof. L. Dudley Stamp deals with the "Conservation of Land". He stresses the importance of reclamation and making the most of what land we have in a country with only half an acre per capita. One acre of fertile land is needed on an average to feed one person. Sir Hugh Beaver describes the damage done by air pollution, the annual cost of which was recently estimated at $£ 260,000,000$. Sulphur is the main offender, so that gasification of coal would reduce this figure considerably. Dr. W. H. J. Vernon lectured on "The Conservation and Corrosion of Metals" and R. M. Finch, the city engineer of Nottingham, describes the way in which waste materials, such as slag, sewage, refuse and ash, can be used, and the reclamation of derelict land. He gave an encouraging account of the steps taken in Nottingham.

\section{Life in Oceanic Trenches}

True first volume of the Galathea Reports to be issued (Scientific Results of the Danish Deep-Sea Expedition round the World, 1950-52. Vol. 2. Pp. $253+4$ plates. Copenhagen : Danish Scientific Press, 1956. 75 Danish $\mathrm{kr}$.) is devoted to papers on animals obtained by the Expedition in depths mainly greater than $6,000 \mathrm{~m}$. When it is realized that only one trawl haul had been made on the sea-bed at this depth (in 1948, by the Swedish Albatross Expedition) before the Galathea Expedition set sail, the importance of this volume is immediately apparent. It contains almost the entire record of creatures existing in the hadal depths of the ocean from $6,000 \mathrm{~m}$. to below $10,000 \mathrm{~m}$. The examination of this material has been hastened because of its importance, and the results are prosented before any of the other findings of the Fxpedition. The leaders of this Expedition have established a new nomenclature for the oceanic depths : the term 'abyss' is now limited to the depths between approximately $3,000 \mathrm{~m}$. and $6,000 \mathrm{~m}$., that is to say, the greatcr part of the oceanic floor; the oceanic trenches below $6,000 \mathrm{~m}$. are referred to as the 'hadal zone'. 'The distinction seems valid, for the fauna of these trenches is greatly different from that of the level oceanic floor. The hadal fauna described in this volume includes Actinaria, hydroids, an octocoral, holothurians (the dominant group of the hadal fauna), crinoids, polychaetes, isopods, pycnogonids and tanaid crustaceans. More than one hundred specimens belonging to five phyla were taken below $10,000 \mathrm{~m}$. The greater part of the hadal species were new to science, but most of them belonged to genera already known. Where new genera are described there is a tendency, strongly to be deplored, to name them after the ship-Galatheanthemum, Galatheathuria, Galathealinum and Galatheathauma are new genera from the hadal or abyssal depths, and not one of them belongs to the family Galatheidae, or even to the same phylum as Galathea. But this is a very minor criticism of a volume which will remain the chief or only reference source for the hadal fauna for decades.

\section{Simple Investigations in Biology}

THE place of the amateur in biological investigation has been brought out by J. E. Marson, rural science organizer to the East Suffolk Education Committee. As a result of investigations in various parts of Britain, Marson showed that nymphs of the water boatman, Notonecta, were to be found in ponds in the West Riding of Yorkshire in the summer and early autumn while adults were found at all times of the year ; in east Suffolk Notonecta nymphs can be found in summer and Notonecta adults can only be found in autumn when there are very few nymphs. If Marson's statements are correct, then in the West Riding of Yorkshire the adults live until the year after they are nymphs, while in east Suffolk they die during the same year as they are nymphs. In an article in School Nature Study (52, No. 208; July 1957) Marson indicates the value of such observations to schoolchildren and asks for the help of children throughout Britain in preparing a national inquiry into the life-cycle of Notonecta.

\section{Zoological Nomenclature}

THE International Commission on Zoological Nomenclature gives notice that, as from March 30, 1958 , it will start voting on the following cases involving the possible use of its plenary powers for the purpose specified against each entry. Full details of these cases were published on September 30 in the Bulletin of Zoological Nomenclature (13, Part 9): (1) Phrynosoma Wiegmann, 1828, validation (Cl. Reptilia, Order Squamata); (2) Pentila Westwood, [1851], validation, and designation for, and for Liptena Westwood, [1851], of type species (Cl. Insecta, Order Lepidoptera); (3) Centris Fabricius, 1804, designation of type species for ; dimidiata Fabricius, validation (Cl. Insecta, Order Hymenoptera); (4) adspersus Rathke, 1837 (Palaemon), protection (Cl. Crustacea, Order Decapoda). A proposal is also made for the adoption of a declaration on the question of the use of the diæresis sign for zoological names. Comments should be sent as soon as possible in duplicate to Francis Hemming, Secretary to the Commission, 28 Park Village East, Regent's Park, London, N.W.1.

\section{Sunspots during November-December 1956}

Two Circulars, Nos. 75 and 76 , of the United States Naval Observatory, by Winifred Sawtell Cameron, give the results of the measurements of sunspots secured at the U.S. Naval Observatory or at the Mt. Wilson Observatory ; these results are a continuation of those published in the Monthly Weather Revieu' from February 1, 1927, until December 31 , 1947. The data appear in tabular form, a full explanation being given of the symbols used. In addition, No. 77, "Solar Summary for 1956", provides additional data and includes for each day a summary of the results for each group which was numbered at $\mathrm{Mt}$. Wilson, a table containing only four entries dealing with unnumbered groups, and a table comprising fifty entries of recurrent groups. 